\title{
Research Paper: Factors Affecting Professional Competency of Iranian Preschool Administrators Based on Crisis Management Approach
}

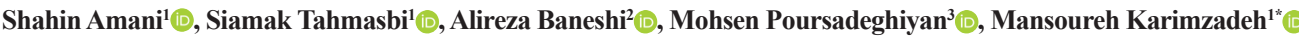

1. Department of Preschool Education, University of Social Welfare and Rehabilitation Sciences, Tehran, Iran.

2. Department of Psychology, Faculty of Psychology \& Education, Allameh Tabataba'i University, Tehran, Iran.

3. Health in Emergency and Disaster Research Center, University of Social Welfare and Rehabilitation Sciences, Tehran, Iran

\begin{tabular}{|l|l|}
\hline $\begin{array}{l}\text { Use your devic to scan } \\
\text { and read the article online }\end{array}$ & $\begin{array}{l}\text { Crtation:Amani Sh, Tahmasbi S, Baneshi A, Poursadeghiyan M, Karimzadeh M. Factors Affecting Professional Competency } \\
\text { of Iranian Preschool Administrators Based on Crisis Management Approach. Health in Emergencies and Disasters Quarterly. } \\
2018 ; 3(4): 185-190 .\end{array}$ \\
\end{tabular}

Funding: See Page 189

(c) Copyright: The Author(s)

Article info:

Received: 11 Nov. 2017

Accepted: 10 Mar. 2018

Available Online: 01 Jul. 2018

\section{Keywords:}

Professional competence,

Educational measurement,

Preschool, Crisis

management

\begin{abstract}
A B STRACT
Background: Children's inability to protect themselves, shows the importance of crisis management in preschool period. Preschool administrators can help them with the risk prevention during crisis. We aimed to investigate the professional competencies of preschool administrators based on crisis management approach.

Materials and Methods: The study participants included 387 preschool administrators in Tehran, Iran, selected by multi-stage cluster sampling method. The surveying tool was a questionnaire designed based on the Child Care Director Self-Assessment instrument (North Carolina Institute, 2015), which has 76 items covering 11 different competency areas. The obtained data were analyzed in SPSS (Version 21) by performing descriptive tests and inferential statistics like the Kruskal-Wallis test and the stepwise linear regression method.

Results: The results showed a significant difference between professional competency of preschool administrators in terms of age, management experience and educational level $(\mathrm{P}<0.001)$. Also, regression results revealed that management experience and educational level can predict professional competency for crisis management, but age could not predict the variation in professional competency $(\mathrm{P}>0.05)$.
\end{abstract}

Conclusion: Administrators who are more professionally competent in terms of technical, human, and perceptual skills are more qualified for the preschool management, but age variables can not predict eligibility.

\section{Introduction}

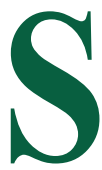

ince its creation, man has been involved in education, as it plays an important role among social institutions [1, 2]. Preschool is the first stage of education system aimed to prepare children for primary schools $[1,3-6]$. Thousands of children and teenagers spend their golden life in schools. Since students are unable to protect themselves from incidents, governments must develop prevention programs, coping skills and crisis control plans at national, regional, provincial and local levels. Even orga-

\section{* Corresponding Author:}

Mansoureh Karimzadeh, PhD

Address: Department of Preschool Education, University of Social Welfare and Rehabilitation Sciences, Tehran, Iran.

E-mail: mkarimz2000@gmail.com 
nizations such as business firms and service providers, hospitals, universities and schools need a comprehensive plan, tailored to their activities in critical incidents [7].

Harmful events, regardless of their severity, lead to various stress response in students like fear, anger, guilt, depression, recalling annoying images, memory loss, difficulty in concentration and learning. These issues can seriously interfere with learning, and complicate normal activities in school. School is where children spend most of their time and much of the learning takes place. Children learn to solve many problems, and receive necessary support through communicating with teachers and administrators. Managers play a critical role in education, and their supportive role is more prominent in the time of crisis [8].

Preschool administrators should prioritize the vulnerability of preschool centers (structural and administrative problems), implement general education (preparedness for crisis in preschool centers), hold periodic meetings with parents and crisis management experts, etc. Crisis manager is the coordinator between service providers and policy makers, and must develop necessary skills in his/her organization [9]. In the event of an earthquake, much help is needed for rescue and relief of preschool children. Therefore, establishing a comprehensive crisis management program is necessary to reduce the risk endangering these children [10].

Studies show that the crisis management determines the extent of damage and not the crisis itself. In fact, inappropriate planning and management of the crisis increases the extent of damages [11]. For this reason, crisis planning and management have become more important than ever. Considering this, in this paper we aimed to investigate the factors related to professional competence of preschool administrators in Iran, based on crisis management approach.

\section{Materials and Methods}

This study examined preschool administrators' professional competencies based on crisis management approach and, statistical population consisted of all preschool administrators in Tehran, Iran $(\mathrm{N}=780)$ in 2017. Using multistage cluster sampling method, 380 preschool administrators were selected as statistical sample from the four regions (north, south, west, and east) of Tehran. For surveying, we used the Child Care Director Self-Assessment instrument presented by North Carolina Institute in 2015 [12].
It has 76 items covering 11 different competency areas (educational knowledge and skills, organizational skills, staff management, technology, educational programming, safety and compliance, communication and managing relationships, parental and family support, financial management, professional contributions, and personal management) rated based on a 5-point Likert-type scale. All Persian translated items were matched with the crisis management approach. The content validity of the tool was approved in consultation with 10 experts. To analyze the collected data, first descriptive statistics (frequency, mean, percentage, standard deviation) were presented. Since the data was non-normally distributed, the KruskalWallis nonparametric test was used, and stepwise linear regression was used to predict the components.

\section{Results}

Of 387 preschool administrators who participated in the study, 373(96.4\%) were females and $11(2.8 \%)$ were males.Most participants $(64 \%)$ had BA or lower educational degree. Of all participants, 39.1\% aged between 30 and 40 years, and the lowest age frequency (12.5\%) belonged to the group of 50 years and older (Table 1). The Kruskal-Wallis nonparametric test was used to determine managers' characteristics in terms of age, management experience and educational level. The results are presented in Table 2 which shows a significant difference between managers with respect to age, management experience and educational level.

The mean scores indicate that professional competence of the administrators with over 20 years of management experience was significantly higher than the competence of the other participants. Since the P was less than the critical value $(0.05)$, there was a significant difference between the professional competences of administrators in terms of management experience. Also, the favorable professional competence was observed in the age group of 41-50 years $($ mean=216.67) and in those with master's degree (mean=220.80).

\section{Regression model}

In order to explore the relation between professional competence of the administrators $(\mathrm{X})$ and demographic characteristics (age, management experience and educational level) (y), stepwise linear regression was used. Measures of model adequacy are presented in Table 3.

The correlation $(\mathrm{R})$ between independent variables and dependent variable is 0.315 and coefficient of determination $\left(\mathrm{R}^{2}\right)$ is 0.09 . This indicates that $9 \%$ of the 
Table 1. Participants' demographic data

\begin{tabular}{ccc}
\hline Group & Range & Percent \\
\hline Age (y) & $20-30$ & 18.1 \\
& $31-40$ & 39.1 \\
& $41-50$ & 27.6 \\
Management experience (y) & $50 \leq$ & 12.5 \\
& $>20$ & 13.2 \\
& $15-20$ & 26.2 \\
Educational level & $6-10$ & 34.3 \\
& High school diploma & 26.2 \\
& Associate degree & 6 \\
& Bachelor's degree & 4.7 \\
& Master's degree & 64.6 \\
& PhD & 23.2 \\
\hline
\end{tabular}

changes between professional competence of the administrators are related to age, management experience and educational level. Also, considering the F-value with $99 \%$ confidence, the regression model is not only significant, but also at least one independent variable is effective in predicting the dependent variable. Regression coefficients are presented in Table 4 . Based on the results, management experience and educational level have a significant relationship with professional competence of preschool administrators, as the predictors, with $99 \%$ confidence $(\mathrm{P}<0.05)$. Age had no significant relationship with professional competence $(\mathrm{P}>0.05)$.

\section{Discussion}

Findings show that the higher the preschool administrators' management experience and level of education, the greater professional competency they will have for

Table 2. Kruskal-Wallis Test results

\begin{tabular}{|c|c|c|c|c|c|}
\hline Variable & Range & Mean & $\mathbf{F}$ & df & Sig. \\
\hline \multirow{4}{*}{$\begin{array}{l}\text { Management } \\
\text { experience }(\mathrm{y})\end{array}$} & $<5$ & 135.76 & \multirow{4}{*}{29.89} & \multirow{4}{*}{3} & \multirow{4}{*}{0.000} \\
\hline & $6-10$ & 197.20 & & & \\
\hline & $15-20$ & 203.05 & & & \\
\hline & $>20$ & 218.90 & & & \\
\hline \multirow{4}{*}{ Age (y) } & $20-30$ & 154.74 & \multirow{4}{*}{15.92} & \multirow{4}{*}{3} & \multirow{4}{*}{0.001} \\
\hline & $31-40$ & 184.97 & & & \\
\hline & & 216.67 & & & \\
\hline & $50 \leq$ & 215.48 & & & \\
\hline \multirow{4}{*}{ Educational level } & High school diploma & 133.93 & \multirow{4}{*}{16.64} & \multirow{4}{*}{3} & \multirow{4}{*}{0.001} \\
\hline & Associate degree & 143.14 & & & \\
\hline & Bachelor's degree & 186.78 & & & \\
\hline & Master's degree & 220.80 & & & \\
\hline
\end{tabular}


Table 3. Correlation between administrators' professional competence and demographic characteristics

\begin{tabular}{cccccc}
\hline $\mathbf{R}$ & $\mathbf{R}^{2}$ & SD & F & Sig. \\
\hline 0.315 & 0.09 & 63.68 & 9.40 & 0.000 \\
\hline & & & & $\begin{array}{c}\text { Illealth in } \\
\text { Emergencies and DDisasters [Oluarterly }\end{array}$ \\
\cline { 3 - 4 }
\end{tabular}

Table 4. Regression coefficients

\begin{tabular}{|c|c|c|c|c|c|}
\hline \multirow{2}{*}{ Model } & \multicolumn{2}{|c|}{ Unstandardized Coefficients } & \multirow{2}{*}{$\begin{array}{c}\text { Standardized Coefficients } \\
\text { Beta }\end{array}$} & \multirow{2}{*}{$\mathbf{T}$} & \multirow{2}{*}{ Sig. } \\
\hline & B & Standard Error & & & \\
\hline Constant & 246.40 & 22.95 & & 10.73 & 0.000 \\
\hline Age & 3.79 & 4.43 & 0.05 & 0.87 & 0.383 \\
\hline Educational level & 19.25 & 4.45 & 0.21 & 4.31 & 0.000 \\
\hline Management experience & -13.73 & 3.98 & -0.20 & -3.45 & 0.001 \\
\hline
\end{tabular}

crisis management. The professional competency of administrators with management experience of more than 20 years were higher, and those with less than 5 years of experience had less professional competency.

Therefore, it can be predicted that preschool administrators with higher experience and level of education can better handle the crisis. Age had no effect on their professional competency. The results of this study is consistent with the findings of Javanmard [13] and Levenson et al. [14] who reported a positive correlation between managerial competence and management experience.

In general, the competencies and skills required for preschool administrators include educational knowledge, organizational skills, staff management skills, use of technology, educational programming, safety and compliance training, communication and relationship management, parental and family support, financial management, professional contributions, and personal management skills.

There are also many commonalities between the competencies of preschool administrators and managers of other organizations; although, the attention of management experts has focused on the technical, human, and perceptual skills. This indicates that these skills (technical, human, perceptual) are not enough to handle crisis management in preschools. Management of educational organizations has certain features that are less common in other organizations; features such as unique organizational relationships, different clients, dealing with teachers as professional people during the crisis, and different beneficiaries (parents, students, and teachers). Such fea- tures require specific competencies and skills in organization management.

Therefore, specific personality characteristics are required for educational leadership. An administrator must have the ability to solve preschool problems, and in facing a crisis, characteristics such as participation, flexibility, proper decision making, accountability, empathy and sympathy, creativity, criticality, responsibility, etc., are necessary. Hence, with more work experience and higher level of education, the abundance and perfection of such features in an administrator is more probable [15].

\section{Conclusion}

We found that the higher the managerial experience and level of education of preschool administrators, the more competent they are to manage the crisis. Managers with more qualification in the aspects of crisis management approach are more competent for the management of preschools to prevent any harm to children in the event of a crisis. Holding workshops through in-service training based on scientific need assessment and the application of new educational approaches for administrators of preschools, can improve their professional competency in this regard.

\section{Ethical Considerations}

\section{Compliance with ethical guidelines}

The current study has been approved by the University of Social Welfare and Rehabilitation Sciences, Tehran, Iran by considering the following codes and ethical 
standards (IR.USWR.REC.1396.89). The participants were informed about the purpose of the research and its implementation stages (Code No.14); The participants were guaranteed confidentiality (Code No.25); The participants were allowed to leave the study whenever they wish, and if desired, the results of the research would be available to them (Code NO.27).

\section{Funding}

This research did not receive any specific grant from funding agencies in the public, commercial, or not-forprofit sectors.

\section{Conflict of interest}

The authors certify that they have no affiliation with or involvement in any organization or entity with any financial interest, or non- financial interest in the subject matter or materials dismissed in this manuscript.

\section{Acknowledgments}

The authors would like to thank the administrators of preschools in Tehran for their valuable cooperation.

\section{References}

[1] Soltani I. [Industrial relations in productional organizations (Persian)]. Isfahan: Ardakan Danesh Publication; 2001.

[2] Safi A. [Education and management of preschool and primary school in Iran and its development (Persian)]. Tehran: Arasbaran; 2012.

[3] Conyers LM, Reynolds AJ, Ou SR. The effect of early childhood Intervention and subsequent special education services: finding for the Chicago child-parent centers. Education Evaluation and Policy Analysis. 2003; 25(1):75-95. [DOI:10.3102/01623737025001075]

[4] Graue E, Clement MA, Reynolds AJ, Ou SR, Niles MD More than teacher directed or child initiated: preschool curriculum type, parent involvement, and children's outcomes in the child-parent centers. Education Policy Analysis Archives. 2004; 12(72):1-38.

[5] Ahmad SSh, Shaari MF, Hashim R, Kariminia S. Conducive attributes of physical learning environment at preschool level for slow learners. Procedia - Social and Behavioral Sciences. 2015; 201:110-120. [DOI:10.1016/j.sbspro.2015.08.138]

[6] Maria-Cristina, F. Portrait of teacher actions from the perspective of school managers. Procedia - Social and Behavioral Sciences. 2015; 180:162-169. [DOI:10.1016/j.sbspro.2015.02.100]
[7] Shirzad Kebria B. [Identifying the main dimensions and components of crisis management in order to offer an appropriate mechanism for high schools in Tehran city (Persian)] Journal of Educational Administration Research Quarterly. 2013; 4(13):85-118.

[8] Motaghipour Y, Bahramnejad A, Mahmoudi Gharaei J, Yasemi MT, Aminesmaeili M. [Psychosocial support in case of unexpected accidents- For teachers and school consultants (Persian)]. Tehran: Ministry of Health and Medical Education, Deputy of Health; 2009.

[9] Keramati MT. [Hidden part: Leadership role in crisis management (Persian)]. Tehran: Keyhan; 2013

[10] Izadkhah YO, Hosseini M. Towards resilient communities in developing countries through education of children for disaster preparedness. International Journal of Emergency Management. 2005; 2(3):138-48.

[11] Dargahi A, Farrokhi M, Poursadeghiyan M, Ahagh MMH, Karami A. Evaluation of functional preparedness and non structural safety of different health units of Kermanshah University of Medical Sciences in coping with natural disasters. Health in Emergencies \& Disasters Quarterly. 2017; 2(4):201-6. [DOI:10.29252/nrip.hdq.2.4.201]

[12] North Carolina Institute. Self-assessment for administrators of child care programs. Chapel Hill: North Carolina Institute; 2015.

[13] Javanmard M. [Students' perceptions of managers' and managers' relationship skills on high school students in Isfahan (Persian)] [MA thesis]. Isfahan: University of Isfahan; 2001.

[14] Levenson AR, Van der Stede WA, Cohen SG. Measuring the relationship between managerial competencies and performance. Journal of Management. 2006; 32(3):360-80. [DOI. org/10.1177/0149206305280789]

[15] Jalili M, Nikfarjam H. [A Survey on the present status of the ability and competencies of the teachers from the perspective of students and the comparison with the ideal situation from the perspective of experts about physics in the fourth grade of high school (Persian)]. Curriculum Planning. 2014; 11(40):129-38 
